УДК 618.15-002:615.454.2:612.085.2:612.063

DOI https://doi.org/10.11603/2312-0967.2019.4.10686

\title{
ВПЛИВ ВАГІНАЛЬНИХ СУПОЗИТОРІЇВ «КЛІМЕДЕКС» НА СТАН СИСТЕМИ ПОЛ- АОС НА МОДЕЛІ НЕСПЕЦИФІЧНОГО ВАГІНІТУ У ЩУРІВ
}

\author{
О. В. Должикова, Л. М. Малоштан \\ Національний фрармацевтичний університет, Харків \\ dolzhikova.elena20@gmail.com
}

ІНФОРМАЦІЯ

Надійшла до редакції / Received: 09.12.2019

Після доопрацювання / Revised: 12.12.2019

Прийнято до друку / Accepted: 13.12.2019

\section{Ключові слова:}

супозиторії;

експериментальний вагініт;

щури;

перекисне окиснення ліпідів; антиоксидантна система.
АНОТАЦІЯ

Мета роботи. Дослідження впливу нових вагінальних супозиторіїв «Клімедекс» на показники системи ПОЛ-АОС на моделі неспецифрічного вагініту у щурів.

Матеріали і методи. Неспецифрічний вагініт моделювали шляхом одноразової внутрішньопіхвової аплікації іританту (суміш скипидару та диметилсульфоксиду) нелінійним щурам-самицям. Компоненти системи ПОЛАОС визначали у сироватці крові та гомогенаті тканин піхви. У сироватці крові визначали вміст ТБК-АП, активність КАТ і СОД, у тканині піхви активність КАТ, вміст ТБК-АП і G-SH. Як препарати порівняння використовували вагінальні таблетки «Мікожинакс» і «Супозиторії з олією обліпихи», рекомендовані для лікування неспецифічних вагінітів.

Результати й обговорення. У результаті проведеного дослідження встановлено, що супозиторії «Клімедекс» на моделі неспецифічного (іритативного) вагініту в щурів виявили антиоксидантну активність. У результаті впливу досліджуваних супозиторіїв «Клімедекс» спостерігали достовірне зменшення вмісту ТБК-АП, збільшення активності КАТ у сироватці крові та гомогенаті піхви, відновлення вмісту G-SH у гомогенаті піхви, а також активності СОД у сироватці крові щурів із неспециорічним експериментальним вагінітом. За активністю зменшувати вміст ТБК-АП і відновлювати вміст G-SH, а також активність КАТ супозиторії «Клімедекс» не поступаються рефреренс-препаратам «Мікожинакс» та «Супозиторії з олією обліпихи», а за здатністю відновлювати активність СОД достовірно перевершують препарат порівняння «Супозиторії з олією обліпихи». Це свідчить про позитивний вплив досліджуваних супозиторіїв на стан прооксидантно-антиоксидантної системи як на місцевому рівні, так і системно, що є позитивним при лікуванні неспецифічного вагініту і буде перешкоджати розвитку системних ускладнень. Висновки. Отримані в результаті експерименту дані дозволяють рекомендувати супозиторії «Клімедекс» для подальшого вивчення як засобу для лікування неспецифрічних вагінітів.
Вступ. Вивчення ролі процесів перекисного окиснення ліпідів (ПОЛ) і антиоксидантної системи (АОС) представляє інтерес у розвитку багатьох захворювань протягом останніх років. За даними літератури, дисбалансом системи пОЛ-АОС супроводжується практично будь-яка патологія, в тому числі захворю- вання репродуктивної системи жінок, включно неспецисрічні вагініти (НB) [1]. Зміну потенціалу пОЛ-АОС на тлі НВ можна пояснити збільшенням рівня обсіменіння умовно-патогенною мікрофрлорою, яка провокує активацію поліморфноядерних лейкоцитів як першої лінії вродженого захисту та ефектора адап-

ISSN 2312-0967. Pharmaceutical review. 2019. № 4 
тивного імунітету. Саме їхнє вивільнення активує надмірне запалення і окиснювальний стрес у піхві, що призводить до продукції активних фрорм кисню (АФК) [2].

Надмірне утворення АФК активує процеси ПОЛ, сприяє пошкодженню широкого спектра клітинних компонентів (мембранних ліпідів, орерментів, ДНК і т.ін.) [3] і призводить до загибелі клітин. Результатом невідповідності між можливостями антиоксидантних ферментів і швидкістю вільнорадикального окислення $€$ зміна рівня тіобарбітурової кислоти-активних продуктів (ТБК-АП), які також відображають ступінь пошкодження клітинних мембран під дією АФК $[3,4]$.

Стан AOC, навпаки, відображає захисні можливості організму та мембран клітин від пошкодження вільними радикалами [3]. Одним із найвідоміших і найбільш вивчених внутрішньоклітинних антиоксидантів $€$ глутатіон, який має потужну детоксикаційну дію. Система глутатіону включає власне глутатіон і ще три орерменти (глутатіонпероксидазу, глутатіонтрансореразу і глутатіонредуктазу) та $є$ єдиною в організмі, яка бере участь у трьох лініях захисту з чотирьох. Наявність достатньої концентрації відновленого глутатіону (G-SH) є критичним фрактором виживання клітин в умовах оксидативного стресу [5].

Ферменти супероксиддисмутаза (СОД) і каталаза (КАТ) також реалізують функції системи антиоксидантного захисту, а зміна їх активності у крові супроводжує велику кількість захворювань запального характеру $[1,6]$. СОД здійснює дисмутацію супероксидного радикалу - продукту одноелектронного відновлення молекулярного кисню (до кисню і перекису водню), який утворюється практично у всіх клітинах організму, що контактують з киснем, і відіграє провідну роль у процесах токсичності АФК [6]. КАТ нейтралізує токсичний перекис водню $\left(\mathrm{H}_{2} \mathrm{O}_{2}\right)$, запобігає його накопиченню, каталізуючи його розкладання до $\mathrm{O}_{2} \mathrm{i}$ $\mathrm{H}_{2} \mathrm{O}$ і не вимагає енергії для активації, а також має вирішальне значення для забезпечення фрункції СОД [1].

Таким чином, з огляду на роль системи ПОЛ-АОС при запальних захворюваннях та її значення в механізмі розвитку НВ, сучасні методи його терапії в комплексному лікуванні повинні включати лікарські засоби з антиоксидантною дією.

За даними літератури, лікування НВ $є$ ефективним як у разі самостійного місцевого використання, так і у комплексному застосуванні (перорально/ парентерально+інтравагінально). За рахунок місцевого застосування створюється більш висока концентрація лікарських засобів у місці патологічного процесу, спостерігається менша кількість лікарських взаємодій і побічних ефектів. Але резистентність мікроорганізмів і труднощі, які виникають у зв'язку з частими рецидивами НВ, створюють потребу пошуку більш ефективних препаратів, які містять рослинну сировину [7].
Розроблені у Національному фармацевтичному університеті під керівництвом профр. Ярних Т. Г. вагінальні супозиторії «Клімедекс», до складу яких входять кліндаміцину фроссрат, метронідазол, фрлуконазол, дексаметазон і обліпихова олія [9], рекомендовані для лікування інфекційно-запальних гінекологічних захворювань.

Тому метою нашого дослідження стало вивчення впливу нових вагінальних супозиторіїв «Клімедекс», які раніше досліджені за антимікробною та протизапальною активністю [9], на показники ПОЛ-АОС на моделі експериментального неспецифічного вагініту у щурів.

Матеріали і методи. Дослідження супозиторіїв «Клімедекс» (1 супозиторій містить: кліндаміцину фросфрат 100 мг, метронідазолу 150 мг, фрлуконазолу 100 мг, дексаметазону 0,5 мг, олії обліпихової 200 мг, суміш ПЕО-1500 і ПЕО-400 (9: 1)) проводили в порівнянні 3 ресреренс-препаратами супозиторії вагінальними таблетками «Мікожинакс» («Мекофрар Кемікал Фармасютікал Джоінт-Сток Компані», В'єтнам; 1 таблетка містить метронідазолу 200 мг, хлорамфеніколу 80 мг, дексаметазону ацетату 0,5 мг, ністатину 100000 МO), близькі за складом і рекомендовані для лікування гінекологічних захворювань, і «Супозиторії 3 олією обліпихи» («Нижфрарм», Росія; 1 супозиторій містить 500 мг олії обліпихи), які мають антиоксидантні властивості.

Дослідження проведено на нелінійних щурах-самицях масою $(190 \pm 20)$ г. Тварини знаходилися на стандартному раціоні віварію. У ході експерименту догляд за ними здійснювали згідно із наявними документами, які регламентують організацію роботи 3 використанням експериментальних тварин. Були дотримані принципи «Європейської конвенції про захист хребетних тварин, що використовуються для експериментальних та інших наукових цілей» (Страсбург, 1986) [10], прийняті I Національним конгресом 3 біоетики (Київ, 2000). Після завершення експерименту щурів виводили з досліду методом декапітації під легким ефірним наркозом відповідно до етичних принципів поводження за тваринами. До початку експерименту у самок щурів був досліджений естральний цикл і відібрані тварини в фразах prooestrusoestrus, для мінімізації розбіжностей в оцінці отриманих результатів.

Вагініт моделювали шляхом одноразової внутрішньопіхвової аплікації суміші іритантів [11]: суміш скипидару (ТОВ «Янтар», Україна) з диметилсульсроксидом (Dimexid, «Arterium», ТОВ «Галичфрарм», Україна) у співвідношенні 1:1 в дозі 0,5 мл/100 г маси тіла тварини. Тварини були розділені на 6 груп по 6 тварин у кожній наступним чином: 1 група - інтактні тварини (ІК, інтактний контроль, без патології), 2 група - контрольна патологія (КП, позитивний контроль), 3 група - тварини, яких лікували вагінальними супозиторіями «Клімедекс» у дозі 33,31 мг/кг (загальної

ISSN 2312-0967. Фармацевтичний часопис. 2019. № 4 
Фармакологічні дослідження біологічно активних речовин Pharmacological researches of biologically active substances

кількості діючих речовин), 4 група - тварини, яких лікували препаратом порівняння вагінальними таблетками «Мікожинакс» у дозі 17,88 мг/кг (загальної кількості діючих речовин); 5 група - тварини, яким вводили препарат порівняння «Супозиторії з олією обліпихи» у дозі 17,64 мг/кг; 6 група - тварини, яким застосовували супозиторну основу в еквівалентній кількості (плацебо; негативний контроль; суміш PEO-1500 і PEO-400 (9: 1). Через 24 години після введення іританту починали лікування. Досліджувані препарати уводили в піхву протягом 7 днів 1 раз на добу вагінально в дозах, розрахованих із використанням застосовуваних в експериментальній фрармакології коефіцієнтів видової стійкості за Риболовлєвим Ю. Р. [12].

Для дослідження показників використовували сироватку крові і гомогенат тканин піхви щурів. Визначення активності компонентів системи ПОЛ-АОС проводили за допомогою спектрофотометра «Sресо|» (Великобританія): у сироватці крові визначали [13] вміст ТБК-АП, активність КАТ і СОД, у тканині піхви визначали активність КАТ, вміст ТБК-АП і G-SH.

Зміни даних показників дозволяють оцінити вираженість запалення, під час якого спостерігається дисбаланс процесів ПОЛ і захисних систем організму. Як показник інтенсивності ПОЛ найчастіше визначають вміст продуктів (ТБК-АП), що реагують 3 тіобарбітуровою кислотою. Під їх впливом відбувається пошкодження клітинних мембран, що є одним із провідних фракторів розвитку запального процесу [4]. Стан антиоксидантної системи оцінювали за вмістом G-SH і активністю антиоксидантних ферментів КАT і СОД [14].
Статистичну обробку результатів проводили за допомогою «Statistica 6.0» 3 використанням критерію Newman-Keuls.

Результати й обговорення. Дані про вплив супозиторіїв «Клімедекс» на стан показників ПОЛ-АОС у щурів на тлі іритативного вагініту представлені на рисунках 1 і 2.

На тлі експериментального вагініту у гомогенаті тканини піхви (рис. 1) у щурів спостерігався дисбаланс у системі ПОЛ-АОС. Рівень КАТ достовірно знижувався майже в 2 рази і G-SH в 1,4 раза, а рівень ТБК-АП достовірно підвищувався в 1,5 раза, що свідчить про виснаження АОС і активацію ПОЛ в тканинах піхви, яке супроводжується пригніченням кисеньзалежних процесів.

Під впливом досліджуваних супозиторіїв «Клімедекс» у тканині піхви спостерігали відновлення антиоксидантного захисту, яке проявляється достовірним підвищенням рівня КАТ в 1,9 раза і зростанням рівня G-SH в 1,3 раза, а також достовірним зменшенням рівня ТБК-АП в 1,58 раза у тканині піхви під впливом досліджуваних супозиторіїв порівняно $з$ групою тварин контрольної патології.

За умов лікування експериментального вагініту супозиторії «Клімедекс» (рис. 1) не поступалися препаратам порівняння «Супозиторії з обліпиховою олією» і таблеткам вагінальним «Мікожинакс» і за ефективністю відновлювати активність КАТ, за ефективністю зменшувати ТБК-АП і відновлювати рівень G-SH у гомогенаті тканини піхви.

На тлі експериментального вагініту в сироватці крові (рис. 2) відбулися достовірні зміни показників системи ПОЛ-АОС характерні для запального процесу [6, 14], зареєстровані достовірне зниження актив-

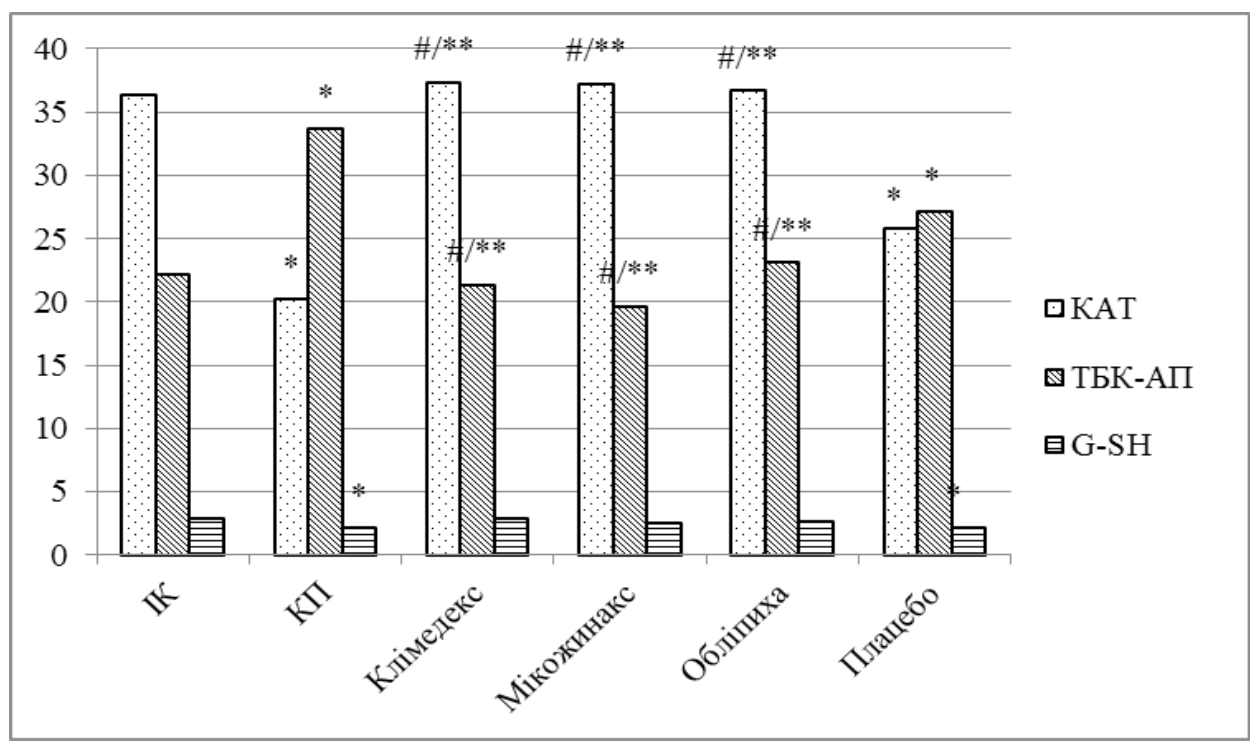

Рис. 1. Рівень КАТ, мкмоль/(хвл) ТБК-АП, мкмоль/г і G-SH, мкмоль/г у гомогенаті піхви щурів на тлі вагініту. Примітка: * - достовірно відносно тварин групи IK ( $<0,05)$; ** - достовірно відносно плацебо $(p<0,05)$; ${ }^{*}-$ достовірно відносно тварин групи КП ( $<0,05)$; ІК - інтактний контроль; КП - контрольна патологія.

ISSN 2312-0967. Pharmaceutical review. 2019. № 4 
Фармакологічні дослідження біологічно активних речовин Pharmacological researches of biologically active substances

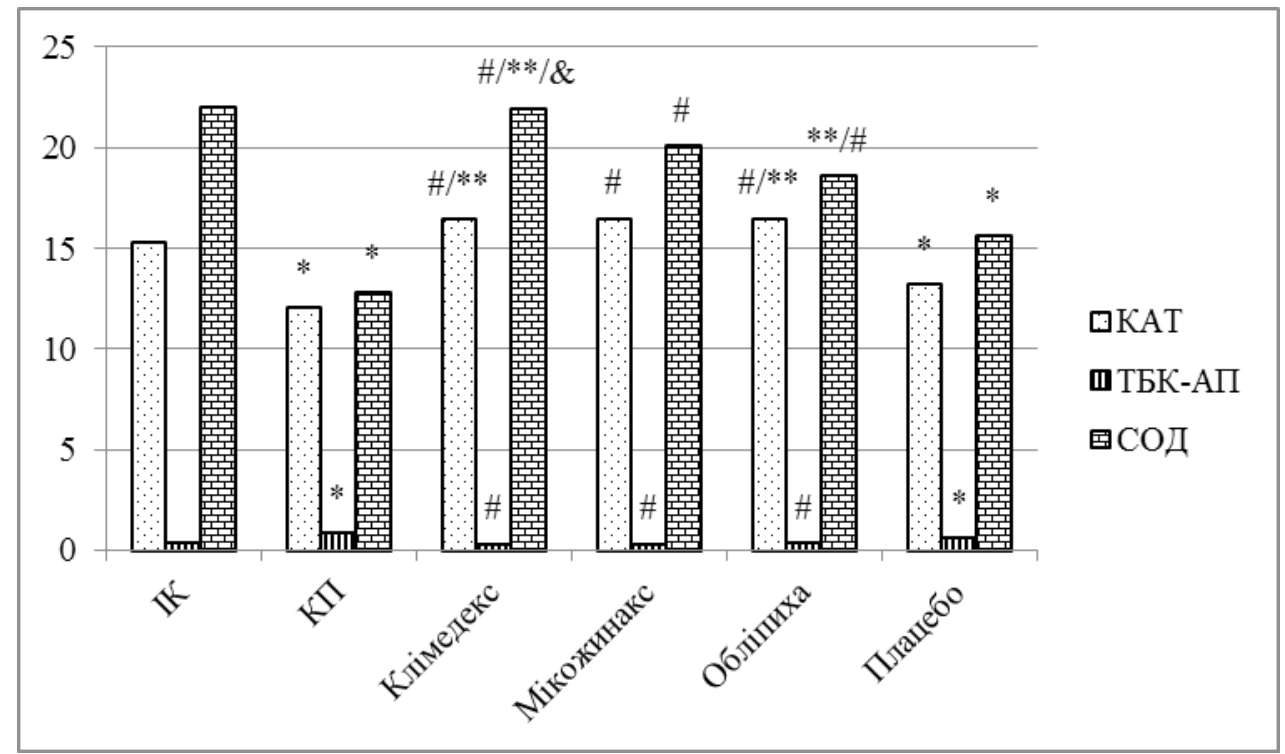

Рис. 2. Рівень КАТ, мкмоль/(хвл), ТБК-АП, мкмоль/г і СОД, ум. од. у сироватці крові щурів на тлі вагініту. Примітка: * - достовірно відносно тварин групи IK (p<0,05); ** - достовірно відносно плацебо $(p<0,05)$; \# достовірно відносно тварин групи КП (p<0,05); \& - достовірно відносно групи тварин «Обліпиха» $(p<0,05)$; IК - інтактний контроль; КП - контрольна патологія.

ності КАТ в 1,3 рази і СОД в 1,7 раза і достовірне збільшення рівня ТБК-АП в 2,25 раза. Це свідчить про системну відповідь організму на патологічні зміни в піхві, які проявляються у виснаженні АОС і активації ПОЛ.

У сироватці крові щурів під впливом досліджуваних супозиторіїв «Клімедекс» спостерігали відновлення антиоксидантного захисту до рівня значень тварин групи IK, що проявляється достовірним підвищенням рівня активності КАТ в 1,4 раза і СОД в 1,72 раза порівняно $з$ тваринами групи КП. Також достовірно зменшувався рівень збільшеного ТБК-АП в 2,59 раза порівняно з тваринами групи КП. Отримані дані свідчать про нормалізуючий вплив досліджуваних супозиторіїв «Клімедекс» на показники ПОЛ-АОС.

У результаті проведеного експерименту встановлено, що супозиторії «Клімедекс» не поступалися рефреренс-препаратам «Мікожинакс» та «Супозиторії 3 олією обліпихи» за активністю зменшувати вміст ТБК-АП і підвищувати активність КАТ в сироватці крові щурів на тлі експериментального вагініту. За здатністю відновлювати знижену активність СОД супозиторії «Клімедекс» достовірно перевершували ресреренс-препарат «Супозиторії з олією обліпихи».

Вміст змінених ТБК-АП, G-SH та активність КАТ у гомогенаті піхви та вміст змінених ТБК-АП та активність КАТ і СОД у сироватці крові в групі тварин, лікованих плацебо, статистично не відрізнялись від групи тварин КП.

Антиоксидантна активність вагінальних супозиторіїв «Клімедекс» може бути пояснена наявністю в їх складі рослинної сировини - обліпихової олії, що під- тверджується даними літератури. Протирадикальна активність рослинних засобів зумовлена присутністю у їхньому складі фенольних сполук, монотерпенових спиртів, кетонів, альдегідів, вуглеводів та ін. [15]. За даними літератури, плоди обліпихи, з яких отримують олію, містять велику кількість біологічно активних речовин, серед яких наявні сполуки фрлавоноїдної структури та вітамін E [16]. Також наявність у складі супозиторіїв «Клімедекс» метронідазолу зумовлює вплив на систему ПОЛ-АОС, у літературі наявні дані, що гель для зовнішнього застосування Метрогіл (1 \% метронідазол) проявляє антиоксидантну активність, а саме здатний зменшувати продукцію нейтрофрільними лейкоцитами АФК, гідроксильних радикалів і пероксиду водню - потенційних оксидантів, які спричиняють пошкодження тканин у місці запалення [17]. Тобто, наявність у складі супозиторіїв «Клімедекс» обліпихової олії і метронідазолу зумовлюють їхні антиоксидантні властивості.

Таким чином, вагінальні супозиторії «Клімедекс» мають антиоксидантні властивості, які полягають у здатності відновлювати знижений рівень G-SH у гомогенаті піхви, активність СОД у сироватці крові, активність внутрішньоклітинного антиоксидантного ферменту КАТ і знижувати вміст ТБК-АП у гомогенаті піхви та у сироватці крові щурів із неспецисрічним експериментальним вагінітом. Це свідчить про позитивний вплив досліджуваних супозиторіїв на стан прооксидантно-антиоксидантної системи як на місцевому рівні, так і системно, що є позитивним при лікуванні неспецифічного вагініту і буде перешкоджати розвитку системних ускладнень [18].

ISSN 2312-0967. Фармацевтичний часопис. 2019. № 4 
Фармакологічні дослідження біологічно активних речовин Pharmacological researches of biologically active substances

Висновки. 1. Експериментально доведено, що вагінальні супозиторії «Клімедекс» у дослідженні на моделі неспецифічного (іритативного) вагініту в щурів виявили антиоксидантну активність, це підтверджує достовірне зменшення вмісту ТБК-АП, збільшення активності КАТ у сироватці крові і в гомогенаті піхви, відновлення вмісту G-SH у гомогенаті піхви, а також активності СОД у сироватці крові щурів із неспецифрічним експериментальним вагінітом.

2. За активністю зменшувати вміст ТБК-АП і відновлювати вміст G-SH, активність КАТ супозиторії «Клімедекс» не поступаються референс-препаратам «Мікожинакс» та «Супозиторії з олією обліпихи», а за здатністю відновлювати активність СОД достовірно перевершують препарат порівняння «Супозиторії з олією обліпихи».

3. Отримані в результаті експерименту дані дозволяють рекомендувати супозиторії «Клімедекс» для подальшого вивчення як засіб для лікування неспецисрічних вагінітів.

Конфлікт інтересів: відсутній

Conflicts of interest: authors have no conflict of interest to declare.

\title{
INFLUENCE OF VAGINAL SUPPOSITORIES "KLIMEDEKS" ON THE STATE OF THE SYSTEM OF LPO- AOS ON THE MODEL OF NONSPECIFIC VAGINITIS IN RATS
}

\author{
O. V. Dolzhykova, L. M. Maloshtan \\ National University of Pharmacy, Kharkiv \\ dolzhikova.elena20@gmail.com
}

The aim of the work. Investigation of the influence of new vaginal suppositories "Klimedeks" on the indicators of LPO-AOS on the model of nonspecific vaginitis in rats.

Materials and Methods. Nonspecific vaginitis was modeled by a single intravaginal application a mixture of terebenthine oil and dimethyl sulfoxide to non-linear female rats. The activity of the components of the system of LPO-AOS was determined in blood serum and vaginal tissues homogenate. Level of TBA-AP, activity of CAT and SOD were determined in blood serum, and activity of CAT, levels of TBA-AP and G-SH were determined in vaginal tissue. As reference drug there were taken vaginal tablets "Micogynax" and "Suppositories with hippophaes oleum" recommended for the treatment of nonspecific vaginitis.

Results and Discussion. The study found that the suppositories "Klimedeks" showed an antioxidant effect on the model of non-specific (irritative) vaginitis in rats. A significant decrease in the level of TBA-AP, an increase in the activity of CAT in the blood serum and in the vaginal homogenate, a restoration of the level of G-SH in the vaginal homogenate, as well as the activity of SOD in the blood serum of rats with non-specific experimental vaginitis were observed as a result of the influence of the studied suppositories "Klimedeks". Suppositories "Klimedeks" are not inferior to the reference drugs "Micogynax" and "Suppositories with hippophaes oleum" in the activity to reduce the level of TBA-AP, to restore the level of G-SH, the activity of CAT and significantly surpassed the reference drug"Suppositories with hippophaes oleum" in the ability to restore the activity of SOD. This indicates a positive effect of the studied suppositories on the state of the prooxidant-antioxidant system, both locally and systemically, which is positive in the treatment of nonspecific vaginitis and will inhibit the development of systemic complications.

Conclusions. The results of the experiment allow us to recommend the suppositories "Klimedeks" for further study as a drug for the treatment of nonspecific vaginitis.

Key words: suppositories; experimental vaginitis; rats; lipid peroxidation; antioxidant system.

\section{ВЛИЯНИЕ ВАГИНАЛЬНЫХ СУППОЗИТОРИЕВ «КЛИМЕДЕКС» НА СОСТОЯНИЕ СИСТЕМЫ ПОЛ- АОС НА МОДЕЛИ НЕСПЕЦИФИЧЕСКОГО ВАГИНИТА У КРЫС}

\author{
Е. В. Должикова, Л. Н. Малоштан \\ Национальный фрармацевтический университет, Харьков \\ dolzhikova.elena20@gmail.com
}

Цель работы. Исследование влияния новых вагинальных суппозиториев «Климедекс» на показатели ПОЛ-АОС на модели неспецифического вагинита у крыс.

Материалы и методы. Неспецифический вагинит моделировали путем однократной интравагинальной аппликации ирританта (смеси скипидара и диметилсульфоксида) нелинейным крысам-самкам. Компоненты системы ПОЛ-АОС определяли в сыворотке крови и гомогенате тканей влагалища. В сыворотке крови определяли содержание ТБК-АП,

ISSN 2312-0967. Pharmaceutical review. 2019. № 4 
Фармакологічні дослідження біологічно активних речовин Pharmacological researches of biologically active substances

активность КАТ и СОД, в ткани влагалища определяли активность КАТ, содержание ТБК-АП и G-SH. B качестве препаратов сравнения использовали вагинальные таблетки «Микожинакс» и «Суппозитории с маслом облепихи», рекомендованные для лечения неспецифических вагинитов.

Результаты и обсуждение. В результате проведенного исследования установлено, что суппозитории «Климедекс» на модели неспецифического (ирритативного) вагинита у крыс проявили антиоксидантную активность. В результате влияния исследуемых суппозиториев «Климедекс» наблюдали достоверное уменьшение содержания ТБК-АП, активности КАТ в сыворотке крови и в гомогенате влагалища, восстановление уровня G-SH в гомогенате влагалища, а также активности СОД в сыворотке крови крыс с неспецифическим экспериментальным вагинитом. По активности уменьшать уровень ТБК-АП и восстанавливать уровень G-SH, а также активность КАТ суппозитории «Климедекс» не уступают референс-препаратам «Микожинакс» и «Суппозитории с маслом облепихи», а по способности восстанавливать активность СОД достоверно превышают препарат сравнения «Суппозитории с маслом облепихи». Это свидетельствует о положительном влиянии исследуемых суппозиториев на состояние прооксидантно-антиоксидантной системы как на местном уровне, так и системно, что является положительным при лечении неспецифического вагинита и будет препятствовать развитию системных осложнений.

Выводы. Полученные в результате эксперимента данные позволяют рекомендовать суппозитории «Климедекс» для дальнейшего изучения в качестве средства для лечения неспецифических вагинитов.

Ключевые слова: суппозитории; экспериментальный вагинит; крысы; перекисное окисление липидов; антиоксидантная система.

\section{Список літератури}

1. Analysis of the oxidative stress status in nonspecific vaginitis and its role in vaginal epithelial cells apoptosis / Z. Chen, Z. Zhang, H. Zhang [et al.] // BioMed Research International. - 2015. - Vol. 2015(ID 795656). - 7 p. doi: org/10.1155/2015/795656.

2. Nguyen G. T. Neutrophils to the ROScue: Mechanisms of NADPH oxidase activation and bacterial resistance / G. T. Nguyen, E. R. Green, J. Mecsas // Front Cell Infect Microbiol. - 2017. - Vol. 7(373). - 24 p. doi: 10.3389/ fcimb.2017.00373.

3. Lipid peroxidation and antioxidant status in vagina microenvironment of patients with several common vaginitis / H. Y. Guo, X. M. Hu, D. D. Han [et al.] // Clinical and Experimental Obstetrics \& Gynecology. - 2013. - Vol. 40 (3). - P. 331-336.

4. Лотоцька О. В. Особливості перебігу вільнорадикального окиснення в гомогенаті печінки щурів при комбінованій дії міді та субтоксичних доз стеаратів калію і натрію / О. В. Лотоцька // Медична та клінічна хімія. - 2016. - № 18 (3). - С. 69-74. doi 10.11603/mcch.2410-681X.2016.v0.i3.6948.

5. Бабак О. Я. Глутатион в норме и при патологии: биологическая роль и возможности клинического применения / О. Я. Бабак // Здоров'я України. 2015. - № 1. - 3 c. - URL: http://repo.knmu.edu.ua/ handle/123456789/11377.

6. Изменение активности супероксиддисмутазы и каталазы в крови и иммунокомпетентных органах крыс с системным воспалением под влиянием непрерывного низкоинтенсивного лазерного излучения видимого диапазона спектра / Н. Б. Горбунова, Л. Е. Батай, А. И. Водчиц [и др.] // Фотобіологія та фоотомедицина. - 2013. - № 1(2). - С. 64-70.

7. Palmeira-de-Oliveira R. New strategies for local treatment of vaginal infections / $\mathrm{R}$ Palmeira-de-Oliveira, A. Palmeira-de-Oliveira, J. Martinez-de-Oliveira // Adv Drug Deliv Rev. - 2015. - Vol. 92. - P. 105-122. doi:10.1016/j.addr.2015.06.008.
8. Пат. 61038 Україна, МГЖ А 61 К 9/02, А 61 К 31/00, А 61K 36/72, А 61 P 15/02. Засіб у фрормі песаріїв для лікування інфекційно-запальних гінекологічних захворювань / Степанова К. О., Должикова О. В., Малоштан Л. М., Левачкова Ю. В., Чушенко В. М., Ярних Т. Г.; заявник та патентовласник Національний фармацевтичний університет. - заявл. 19.11.2010; опубл. 11.07.2011, Бюл. № 13.

9. Степанова К. О. Експериментальне обґрунтування використання нових песаріїв «Клімедекс» при лікуванні вагінітів : дис. ... канд. фрармац. наук: 14.03.05 - фрармакологія / Нац. фрарм. ун-т. - Харків, 2012. - $188 \mathrm{c}$.

10. European convention for the protection of vertebral animals used for experimental and other scientific purpose. Council of Europe 18.03.1986. - Strasbourg, 1986. $52 \mathrm{p}$.

11. Пат. 95741 Україна, МПК (2006.01), А61К 31/565, A61K 31/197, A61K 9/02, A61P 15/08, A61P 15/12. Фармацевтична композиція для лікування захворювань урогенітальних органів / Рудько А. Ю., Солнцева А. В., Усоєва Л. А., Моругіна Л. В.; заявник та патентовласник Откритоє акціонєрноє общєство «Ніжегородскій хіміко-фрармацевтічєскій завод». заявл. 16.08.2010 ; опубл. 25.08.2011, Бюл. № 16.

12. Рыболовлев Ю. Р. Дозирование веществ для млекопитающих по константам биологической активности / Ю. Р. Рыболовлев, Р. С. Рыболовлев // Доклады АН СССР. - 1979. - Т. 247. - № 6. - С. 15131516.

13. Методы оценки свободно-радикального окисления и антиоксидантной системы организма / [Арутюнян А. В., Дубинина Е. Е., Зыбина Н. Н.]. СПб. : Фолиант, 2000. - 104 с.

14. Effect of extracts of cryopreserved piglet skin fragments on state of pro- and antioxidant systems following skin cryodestruction / A. A. Vlasov, G. A. Kovalov, I. V. Belochkina [et al.] // Problems of Cryobiology and

ISSN 2312-0967. Фармацевтичний часопис. 2019. № 4 
Cryomedicine. - 2016. - Vol. 26 (2). - 170. doi: $10.15407 /$ cryo26.02.170.

15. Vitro evaluation of antioxidant and antimicrobial activities of Melaleuca alternifolia essential oil / X. Zhang, Y. Guo, L. Guo [et al.] // Biomed. Res. Int. - 2018. Vol. 2018(3). - P. 1-8. doi: 10.1155/2018/2396109.

16. Определение антиоксидантной активности извлечений из плодов облепихи крушиновидной / О. В. Тринеева, И. И. Сафонова, Е. Ф. Сафонова [и др.] // Вестник ВГУ. - 2012. - № 2. - С. 266-268.

\section{References}

1. Chen Z, Zhang Z, Zhang H, Xie B. Analysis of the oxidative stress status in nonspecific vaginitis and its role in vaginal epithelial cells apoptosis. BioMed Research International. 2015;2015(ID 795656): 1-7. doi. org/10.1155/2015/795656.

2. Nguyen GT, Green ER, Mecsas J. Neutrophils to the ROScue: Mechanisms of NADPH oxidase activation and bacterial resistance. Front Cell Infect Microbiol. 2017;7(373): 1-24. doi: 10.3389/fcimb.2017.00373.

3. Guo HY, Hu XM, Han DD, Wang ZP, Meng L. Lipid peroxidation and antioxidant status in vagina microenvironment of patients with several common vaginitis. Clinical and Experimental Obstetrics \& Gynecology. 2013;40(3): 331-6.

4. Lototska OV. [Features of free oxidation in liver homogenates of rats in combined action of copper and subtoxic level of stearate potassium and sodium]. Med $i$ klin khim. 2016;18(3): 69-74. Ukrainian. doi 10.11603/ mcch.2410-681X.2016.v0.i3.6948.

5. Babak OYa. [Glutathione in norm and pathology: the biological role and clinical possibilities]. Zdorovia Ukrainy. 2015;1:1-3. Russian. Available at: http://repo.knmu.edu. ua/handle/123456789/11377.

6. Gorbunova NB, Batay LE, Vodchits AI, Ulastchik VS, Orlovich VA. [Changes in activity of superoxide dismutase and catalase in blood and immunocompetent organs of rats with systemic inflammation under influence of continuous-wave low intensity visible laser radiation]. Fitobiolohiia i eksperym fotomed. 2013;1(2): 64-70. Russian.

7. Palmeira-de-Oliveira R, Palmeira-de-Oliveira A, Martinez-de-Oliveira J. New strategies for local treatment of vaginal infections. Adv Drug Deliv Rev. 2015;92: 10522. doi: 10.1016/j.addr.2015.06.008.

8. Stepanova KO, Dolzhykova OV, Maloshtan LM, Levachkova YuV, Chushenko VM, Yarnykh TH inventors; National University of Pharmacy, assignee. [The reme$d y$ is in the form of pessaries for the treatment of infectious-inflammatory gynecological diseases] UA 61038 (Patent) 2011 Jul 7. Ukrainian.

9. Stepanova KO. [Experimental confirmation using new
17. Nishimuta K. Effects of metronidazole and tinidazole ointments on models for inflammatory dermatitis in mice / K. Nishimuta, Y. Ito // Arch Dermatol Res. - 2003. Vol. 294. - P. 544-551. doi: 10.1007/s00403-002-0381-4

18. Состояние прооксидантно-антиоксидантной системы крови и мышечной ткани крыс при экспериментальном реперфузионном синдроме / О. А. Мальченко, Л. В. Анисимова, М. И. Федосов [и др.] // Таврический медико-биологический вестник. - 2014. - T. 17, № 2 (66). - С. 90-93.

pessaries "Klimedeks" in the treatment of vaginitis]. Candidate's thesis. Nat Pharm Univ. Kharkiv, 2012. Ukrainian.

10. European convention for the protection of vertebral animals used for experimental and other scientific purpose. Council of Europe 18.03.1986. Strasbourg, 1986.

11. Rudko AY, Solntseva AV, Usoieva LA, Morugina LV. inventors; Public corporation "Nizhegorodskiy Chemical-Pharmaceutical Plant", assignee. [Pharmaceutical composition for treatment of diseases of the urogenital organs] UA 95741 (Patent) 2011 Aug 25. Ukrainian.

12. Rybolovlyev YR, Rybolovlyev RS. [Dosing substances for mammals according to the constants of biological activity]. Reports of the USSR Academy of Sciences, 1979;247(6): 1513-6. Russian.

13. Arutyunyan AV, Dubinina EE, Zybina NN. [Methods for assessing free radical oxidation and the antioxidant system of the body]. Saint-Petersburg: Foliant; 2000. Russian.

14. Vlasov AA, Kovalov GA, Belochkina IV, Tynynyka LN, Sandomirsky BP. Effect of extracts of cryopreserved piglet skin fragments on state of pro- and antioxidant systems following skin cryodestruction. Problems of Cryobiology and Cryomedicine. 2016;26(2): 170. doi: 10.15407/cryo26.02.170.

15. Zhang X, Guo Y, Guo L, Jiang H, Ji Q. In vitro evaluation of antioxidant and antimicrobial activities of Melaleuca alternifolia essential oil. Biomed Res Int. 2018;2018(3): 1-8. doi: 10.1155/2018/2396109.

16. Trineeva OV, Safonova II, Safonova EF, Slivkin AI. [Determination of antioxidant activity of extraction from fruit of sea buckthorn]. Vestn VGU. 2012;2: 266-8. Russian.

17. Nishimuta K, Ito Y. Effects of metronidazole and tinidazole ointments on models for inflammatory dermatitis in mice. Arch Dermatol Res. 2003;294: 544-51. doi: 10.1007/s00403-002-0381-4.

18. Malchenko OA, Anisimova LV, Fedosov MI, Kubyshkin AV. [The state of protooxidant-antioxidant system of the blood and muscular tissue of rats at experimental reperfusion syndrome]. Tavrich med i boil vestn. 2014;17,2(66): 90-3. Russian. 
Фармакологічні дослідження біологічно активних речовин

Pharmacological researches of biologically active substances

\section{Відомості про авторів:}

Должикова О. В. - канд. фрармац. Н., доцент кафедри клінічної лабораторної діагностики, Національний фрармацевтичний університет, Харків, Україна. E-mail: dolzhikova.elena20@gmail.com, ORCID 0000-0002-1660-4613 Малоштан Л. М. - д. біол. н., профресор, завідувач кафедри фрізіології та анатомії людини, Національний фрармацевтичний університет, Харків, Україна. E-mail: Inm004@gmail.com, ORCID 0000-0003-1904-9579

Information about the authors:

Dolzhykova O. V. - PhD (Pharmacy), associate professor of the Clinical Laboratory Diagnostics Department, National University of Pharmacy, Kharkiv, Ukraine. E-mail: dolzhikova.elena20@gmail.com, ORCID 0000-0002-1660-4613

Maloshtan L. M. - DS (Biology), Professor, Chief of Physiology and Human Anatomy Department, National University of Pharmacy, Kharkiv, Ukraine. E-mail: Inm004@gmail.com, ORCID 0000-0003-1904-9579 